\title{
The Poet and his Public in La maison fermée
}

\author{
Larissa Christina Bibbee \\ University of Pennsylvania, Philadelphia
}

The question of the poet's relationship with society is one that lies at the heart of Claudel's $5^{\text {th }}$ Ode, la Maison fermée. From the beginning to the end of the Ode the poet strives to find his place, define his role and fulfill his responsibility vis-à-vis his fellow human beings. For the poet, society can be divided into two major categories: on the one hand there are those who reject both God and God's faithful people (the drama-loving public, the rationalists, the pillagers), and on the other hand, there are the actual or potential members of the Church who center (or will center) their lives upon God (the living faithful, the saints and the souls in Purgatory). The poet's relationship with the former (enemy) group is combative; he persistently resists and distances himself from them because they refuse to accept his spiritual word and try to dissuade him from producing it. With respect to the latter (friendly) group the poet has a three-fold mission or responsibility which revolves around the creation of relationships through the communication of a spiritual word which emanates from his own intimate connection with God: first he tries to draw each believer (or potential believer) into a rapport with God that parallels his own; second, he strives to create the community of Church, that is, an affiliation between those individuals who are personally and collectively cultivating an affinity with God; and finally, he endeavors to establish an intimate tie between himself and these members of the Church to whom he ministers. The Ode traces a dramatic evolution from a relationship of confusion and alienation between the poet and an "enemy" public to one of harmonious and mutually supporting communion orchestrated by the poet between himself, God and all living and deceased members of the Church. ${ }^{1}$

The Ode opens with the angry voices of the poet's former public who, in a tirade directed towards the poet, announce a complete breakdown in their relationship with him. The poet was once, they explain, one of them, and he offered them a word that responded to their needs and desires; but he has since changed his ways and thereby sorely disap- 


\section{Larissa Christina Bibbee}

pointed their expectations. They claim that their one-time spokesman has breached his contract with them by usurping and distorting society's language and failing to deliver on the monetary investment made in his education $[6]^{2}$. Now that the poet has retreated into his secure and comfortable "grande maison carrée aux murs épais" [10] he no longer writes dramatic plays for the theatre which seemed to offer some intelligible and definitive meaning or "completeness" [3] to human existence. The expublic looked to the poet's theatre as a means of denouncing and thereby combating and exorcizing the misery, ills and injustices of the human condition [8]. Tragic drama provided them with a venue for their feelings of revolt [8], while theatrical comedy apparently also offered them some degree of solace against the travails of life [5].

Unlike the human solidarity exemplified by and promoted by his theatre, the poet's current lyric poetry seems to this public to be a strictly personal undertaking which is unconcerned with human affairs. Moreover they consider his new poetic word to be incomprehensible, unfamiliar and beyond the ambit of human reality [7,12, 13]. Even though the public does indeed recognize that the poet enjoys a certain happiness within the walls of his maison fermée -they berate him after all for seemingly belonging to the clan of "les satisfaits" [8] and living "sans aucun souci" [9], in a sort of festive Elysian paradise [11-12] - they refuse the inexplicable and mystical nature of his joy. Moreover, this joy appears to be inextricably mixed with and adulterated by a mysterious and suspect "douleur" $[4,14]$ which they also reject as they reject all suffering. ${ }^{3}$

The first person who responds to the ex-public's tirade is the poet's wife who calls herself his "gardienne". Her responsibility is to draw the poet into the maison fermée, that is away from his ex-public who are outside the walls of the house and towards God who occupies the center of the house. The walls of the maison fermée enclose its occupants (the poet, his wife and God) together in a closed space, thereby placing them in a situation of proximity which allows (obliges) them to enter into relationship with each other. The poet and his wife's common focus on God's presence at the center of the house (or in the center of the poet's heart and mind of which the house is a metaphor) is what links them together in a permanent, necessary and structured relationship. In contrast, the poet's relationship with his former public, not centered on God or sustained by any supporting walls, was characterized by precariousness and 
by "hasard" [28], that is, by coincidence or chance rather than by deliberate choice and design. The order and walls of the maison fermée of marriage make it at once a place of penitence and a place of joy (the mixing of which the public did not approve). By comparing the house/marriage to a cloistered monastery [19] and acknowledging that it is not as beautiful as the lover's house in the Song of songs [20], the poet indicates that self-sacrifice is necessary in marriage; but the house is also "la demeure bénite", a quiet refuge that protects its inhabitants from inclement weather [21] (and the clamoring public).

In the last line of her speech la gardienne begs the poet to remain within the maison fermée with her and warns him to avoid succumbing to the temptation of wandering back outside of the house and doing what he once used to do-that is, selling his word to his public: "Tu as donné ta parole. Garde-la pour qu'elle te garde et ne va pas en faire commerce comme du vieux vêtement que l'on vend au Chananéen" [37]. She thus implies that the poet's relationship with his former public had amounted to a sort of commercial transaction. The public had likewise qualified its interaction with the poet in mercantile terms [6]. They had imagined that the poet's word was something that they could purchase and thereby possess and control, while the poet for his part presumably sold (prostituted) his word in exchange for the public's adulation and stamp of approval. Whereas the poet's former word was a linguistic construct concerned only with the most basic human level of reality, the mystical word that he now receives from God and disinterestedly shares with his family is associated with prayer [18] and represents an actual participation in God's life force [24-6]. In transmitting the word from God to his family the poet is also required to give away his true self, his priceless intrinsic spiritual being (his "vie" and his "âme" $[24,30]$ ). By contrast, the word he sold to his public was a mere superficial version of himself or even something completely external to him like a piece of cast-off clothing, a "vieux vêtement" [37].

After the discourse of la gardienne the poet responds to his expublic in similar terms. The poet explains that his current task-one which is complementary to his role as life-giver for his wife and childis to be, like Christopher Columbus, "le rassembleur de la terre de Dieu" [53]. The poet's exploration of the universe reveals to him God's hidden presence in all things, especially in the stars of the celestial sphere. He discovers the geometrical order and the system of interrelationships that exist among all the stars owing to the closed boundaries of the universe. 


\section{Larissa Christina Bibbee}

Discrediting the common myth that the stars are terrifying, alien entities far-removed from humanity, the poet establishes an intimate relationship between him and them [76-78]. At the same time that he finds God's presence in the stars and becomes more familiar with them, he also discovers God's presence in himself and grows closer to God.

The poet explains to his public that his new poetic task as "rassembleur de la terre de Dieu" [53], is far superior to all mere human joys and glories [47-52]. Therefore he insists that he will no longer allow his public's egotistical desires for easy entertainment to compromise the purity and integrity of the "parole" that he produces in the pursuit of his new vocation [39]. Now that he has discovered the spiritual word which alone can afford an authentic remedy for human frustration and unhappiness, he considers his former raucous crowd-pleasing plays to be capable of providing nothing better than a specious and transient emotional catharsis (making people laugh or cry [39]). And yet because the poet's new spiritual word is no longer ostensibly fun and exciting but rather contemplative, peaceful, slowly evolving, and challenging, it does not attract a large audience: "Celui qui fait beaucoup de bruit se fait entendre, mais l'esprit qui pense n'a pas de témoins" [43]. Yet the poet does not produce an abstruse word with the deliberate aim of excluding or exasperating the rest of humanity (as his ex-public had imagined). Although he cannot and must not water down the mystical nature of his word to make it more palatable and easily digestible for his public, he does invite them to boldly undertake the task of earnestly confronting it: "Je n'ai pas à faire de vous, à vous de trouver votre compte avec moi/ Comme la meule fait de l'olive et comme de la plus revêche racine le chimiste sait retirer l'alcaloïde." [45-6] Trying to welcome and understand the spiritual word which seeks to express God's presence in the universe and in the self is, like crushing olive and extracting medicine from a root, a difficult endeavor for anyone who attempts it (poet and public alike). Yet, the poet implies, it is not an impossible task, and the end result of this probing action-the release and acquisition of nutritive (olive oil) and medicinal (alcaloïde) elements, symbols of the exquisite spiritual benefits of the poet's life-giving word-is worth the sacrifice it requires.

This initial (rather passive) invitation which is seemingly addressed to all the members of the poet's ex-public and which may or not be heeded, is followed, several verses later, by a more pro-active offer of the word to a more select audience of those who are truly open to 


\section{The Poet and his Public in La maison fermée}

receiving it. Before embarking upon his mission of naming and unifying the universe, the poet begs God to grant him the ability to receive the richness of God's presence into himself so that he can then actively share it with others: "O mon Dieu, qui avez fait toutes choses donnables, donnez-moi un désir à la mesure de votre miséricorde!/ Afin qu'à mon tour à ceux-là qui peuvent le recevoir je donne en moi cela qui à moi-même est donné" [58-9]. The public with whom the poet now envisions the possibility of actively sharing his word would be willing and able to welcome it. It is not clear however whether he would be targeting a completely new group of people or perhaps certain members of his expublic who will have experienced a change of heart.

The poet's tasks of celebrating God's presence in the universe and of transmitting the living word to his family seemed initially to separate him from humanity, but now they serve as blueprints of his vocation with respect to society. If the poet was able to discover God's image in the stars which once seemed so distant and terrifying, he reasons that he can also find God in the hearts of all men if he considers them as extended members of his own family, "mes frères qui sont tous les hommes, pareils à ma femme et à mon enfant" [84]. The poet clearly indicates that both the word he now offers his public as well as his attitude towards them has changed from the time when he was on good terms with his former drama-loving public. He underscores the fact that he does not try to please his public and that he seeks no personal glory, gain or recognition for his transmission of the word-rather he freely, generously and humbly gives it away as he himself received it as a gift from God $[95,98]$. The word that the poet offers his public is not a futile word like a "vieux vêtement" [37] that he once sold to his ex-public but rather is one which transmits God's presence [107, 123], the divine image constitutive of the essential identity of each person [89-90] through the mediation of the poet's own soul [93]. The poet portrays his new word metaphorically as an organic product of nature (grain, fruit, seed) rather than as the literary or linguistic entity that appealed to his ex-public. The poet's new word is not something to be appreciated on a simply intellectual level or enacted upon a stage by actors outside of the self, but rather a spiritual nutriment meant to be absorbed into the soul and lived out in the context of real life.

The poet's mission to the public no longer separates him from or compromises his relationship with God as before, but rather flows directly out of it. And his relationship with God, although still admit- 


\section{Larissa Christina Bibbee}

tedly primary, no longer precludes him from establishing a certain degree of intimacy with his public. When the poet first receives the word from God in his heart it is like a small but burgeoning seed whose growth potential has not yet been realized. He therefore asks God to help him nourish it and make it germinate into something like a fertile harvest of grain [94] or fruit [95]. This development of the seed represents on the one hand the progressive and continual deepening of the poet's own relationship with God. But at the same time it constitutes the means through which the word is disseminated to the rest of humanity. It is thus the poet's dynamically thriving relationship with God that allows him to produce a rich harvest of God's word for his public. But the poet's reception and growth of the seed within himself is not just a prerequisite for the public to be able to receive the word but also a model for what they themselves must do with the word that they receive. After asking God to make him a fertile wheat field and fruit tree the poet implores God to make him a humble, efficacious sower who no longer offers God's word to his public in the form of a ripened grain or fruit but rather sows it in their hearts in the form of a fledgling seed, that is, in the form that he himself received it. The public must then actively respond to the wordseed and make it grow into a "plante spécifiée" [102] within themselves just as did the poet.

The poet is not only interested in producing the word for his public through his own relationship with God; he also displays a direct interest in helping them cultivate it. Therefore he sows in them not only the word-seed itself, "la mesure de Dieu" [100], but also the conditions necessary for its successful implantation and growth- "silence..... ténèbres..... églises" [99]. Although each person develops their own unique and private relationship with God, the poet to some degree participates in the special relationship between his listener and God just as he allows them to participate in some measure in his own intimate relationship with God. The poet envisages the cultivation of the word-seed in the heart of the listener as a three-way interactive effort between the listener, himself and God: on the one hand the poet asks God to endow his listener with a receptive disposition to his word [105-6], and on the other he himself directly exhorts his listener to create a proper dwelling place, a maison fermée, within his/her heart for the seed of God's presence [107-108]. Although in his direct address to his public the poet appeals to all those who are "bonne terre" [102] - that is capable of responding positively to his word- he nonetheless underscores his intimacy with 


\section{The Poet and his Public in La maison fermée}

and attention for each particular individual by addressing them as "tu" [107-8].

The poet goes on to recall his own past conversion as a model of how to properly receive and nurture the spiritual word-seed. He describes his conversion as a series of solitary candlelight vigils before a massive statue of the crucified Christ ${ }^{4}$ followed by a figurative descent into Christ's tomb in the silent, dark, enclosed space of the Notre Dame cathedral. The cathedral-tomb here represents another type of maison fermée which now binds the poet and Christ together in a close-knit relationship and protects them from the rationalist enemies who dominate the world outside [112]. The candlelight that the poet persistently holds up to Christ's face [111] during "ces sombres après-midi d'hiver à NotreDame" [110] symbolizes the progressive advent of God's word-presence into his heart. ${ }^{5}$ (The image of light taken to represent the gift of God's presence here is analagous to the preceding image of the word-seed). The divine image that the poet sought/ seeks in the universe [67] and within his child (whom he compared to the infant Jesus [36]) he now sees (more plainly) in Christ's face. It is ultimately only through Christ, and specifically through Christ's passion and death and his own participation in it, that the poet can receive the word from God and then offer it to others.

After a period of solitary vigils, the poet descends into Christ's tomb, at which point all the rationalist enemies disappear (falling in masks at his feet) and the tomb, like his previous marital abode, expands out to engulf the entire universe. The poet then claims to light the stars in the heavens with the same candle that he used to illuminate Christ's face in the cathedral, like a person in a religious procession imparting light from his candle to the candles of other worshippers [117-8]. Insofar as the candlelight in question represents the spiritual imprint of Christ's divine presence upon the poet's heart, his lighting of the stars undoubtedly symbolizes his ability to awaken God's presence in the universe as a result of his own personal contact with God. But if one interprets the stars here as representing not merely luminous balls of matter that reflect God's geometry [70] but, more importantly, as symbols of the saints who keep vigil around God's throne, then the poet's lighting of the stars is a figuration of what will happen after death when the poet and his fellow brethren with whom he now shares the light of Christ will exit the tomb of conversion and enter into God's presence. They will then no longer be obliged to look at a mere image of Christ (statue or universe) and thus only enjoy a partial or veiled experience of God (symbolized by the weak 


\section{Larissa Christina Bibbee}

candlelight), but will gaze directly at God's face and be filled with the fullness of God's presence (symbolized by the starlight).

For the present moment, however, neither the poet nor his public are yet star-saints. The members of the public have been drawn into the closed space of Christ's tomb along with the poet and they have received the seed/ light of God's presence from him, but this seed/ light has not yet reached its full potential of growth/ radiance. Before this happens they must engage, in the company of the poet, in the type of slow and silent conversion at which the poet's ex-public once balked [41-4]: "Et le réduit où nous recevons le Seigneur croît plus silencieusement en nous que le temple de Salomon [...]" [120]. The present tense of the verbs in verse 120 indicates that the dwelling place of the heart which welcomes God is still expanding in order to make ever more room for its Divine Guest. The difficulty and self-sacrificial nature of this conversion, or progressive intensification of God's presence, is suggested by the assimilation of the temple of the heart to Christ's tomb and to the marital abode which is less beautiful than the lovers' house in the Song of songs [119]. But, as the poet implies through his lighting of the stars, the end result of this process of conversion is the victory and joy of becoming a star-saint.

The poet makes it clear that if he encourages his public to risk the adventure of life in the maison fermée it is not on the basis of his own whim or authority. Rather he exhorts his public to listen to the Gospel [121] which recommends as examples to all believers three Biblical figures each of whom constructed their own type of maison fermée. These three Biblical models - the true disciple who prays to God in private far from the public eye, the prophet Noah who saved all the animals of creation by gathering them into his ark, and the fictional protagonist of a Gospel parabole who declines to help a friend begging for bread because he is sleeping with his family- seem to be exactly the ones that the poet has already emulated in his own life (first, by spending time alone with God and then by communing with the universe and with his family, and finally even with humanity ${ }^{6}$ ). Thus, the poet first listens to Christ's exhortation in the Gospels to imitate these models (or in the case of Noah he listens to the author of Genesis who is a nonetheless a precursor of Christ) and then dutifully puts them into practice in his life. He then transmits Christ's commands to his public through the mediation of his own voice and example. 
The poet goes on to present still two more variations of the maison fermée of the universe and the conjugal home which he himself experiences and which he invites his public to share. The poet had earlier warned his public that God could not dwell in their hearts if they were like leaky vases [109]. He now presents himself as a "vase inépuisable" [132] containing a microcosmic version of the universe [137] which he freely offers to all of humanity: "Non point pour moi seulement mais pour tout homme qui veut y mettre la lèvre" [133].7 The four axes of the globe $(\mathrm{N}, \mathrm{S}, \mathrm{E}, \mathrm{W})$ then become symbols of the moral virtues of Prudence, Fortitude, Temperance and Justice which, in the manner of la gardienne, keep the poet within the maison fermée of God's laws by regulating his personal relationship with God as well as with humanity. Just as he offers the universe to all who choose to drink from the vase of his spirit [133] the poet also proposes the four moral virtues as examples to imitate for those who wish to follow in his footsteps. Although he speaks mainly in the first person in the course of his description of these virtues, he also intersperses several "nous" pronouns [152, 182, 184, 185] and resorts to many generalizations in order to indicate that these virtues are not only for him but are also meant to be developed by the public. The virtue which deals most directly with the poet's interactions with society is the virtue of Justice: Justice allows him to fulfill his debts to his brethren by transforming the material into the spiritual.

Now that the poet has again spent some quality "contemplative" time filling the vase of his heart and mind with the signs of God's presence in the universe and cultivating the inner moral virtues that allow him to properly relate to God and to society (and encouraging his listeners to do the same), he can safely go back to his active life in the midst of society. He enthusiastically greets the dawning $20^{\text {th }}$ century, and this despite the fact that certain anti-religious segments of society have aligned themselves against the interests of the Church to the point of desecrating and looting certain Church buildings [208-210]..$^{8}$ But just as the poet succeeded in overcoming the pressure and intimidation of his former enemies (his angry ex-public and the rationalists) by escaping to a maison fermée where they could not harm him, he now declares victory over the pillagers insofar as he has discovered a new sacred Church space -the entire universe- - to replace the structures ruined by the pillagers. Unlike the poet's previous confrontations with his enemies when he enjoyed the company only of la gardienne or of Christ, he now has the support, understanding and fellowship of at least a certain segment of 


\section{Larissa Christina Bibbee}

society-those who have already drunk from the vase of his spirit [1323], welcomed his word, and become faithful believers. It is primarily to these friendly fellow Christians that his opening salutation to the "siècle" [206] is addressed.

A host of first person plural pronouns and possessive adjectives $[211,215,217,218,222,224]$ indicates that it is in the company of these fellow believers that the poet now communes with the universe that he once explored very much on his own [60-81]. His second exploration of the celestial sphere now shows him, as before, that there is no "terreur" and no "monstres" to be found therein [221-2]. Rather, the heavens are full of signs of God's "mesure" and "bonté" [ 223] and are completely out of reach of the malice of the enemy pillagers. The geometrically ordered stars and harmoniously orbiting planets that the poet discovers along with his brethren in the celestial sphere are evidence not only of a perfectly ordered material cosmos but are also symbols of saints, that is, those human souls who have not only escaped the physical presence of the enemies but also have been purified from all the moral evil that the enemies exemplify. The poet warmly salutes these stars, praises them and looks to them for guidance and inspiration [234-239].

Unlike in the beginning of the Ode when the poet imagined himself to be separated from a compromised social scene in the maison fermée of marriage and of the universe, his current vision of the star-saints makes him realize that he and the living brethren whom he represents do not (yet) belong to their celestial company. Compared to the star-saints who reflect God's glory perfectly [237], the living faithful appear to the poet to be like gestating stars who are still enveloped in the obscurity of nebulae, "dans la boue et sous le déguisement pareils à des étoiles souffrantes!" [229]. This "boue" and "déguisement" -recalling the masks of the enemies which fell at the poet's feet at the moment of his entrance into Christ's tomb at Notre Dame [115] - symbolize not only the deleterious external environment in which the living faithful are forced to live (among the likes of the pillagers) but also their own unfortunate complicity in the evil which surrounds them. Indeed the incursion of the flesh and blood pillagers into the sacred space of the Churches [210] seems to be not only a sign of the spiritual iniquity which motivates the pillagers themselves but also of the evil which still contaminates the hearts and minds of the poet and the faithful believers whom he represents. 


\section{The Poet and his Public in La maison fermée}

Before the poet can become the star-saint he so ardently desires to be [238] (along with the rest of the faithful whom he invites to follow his lead [243-8]) he must expel the spiritual enemies who are still within the sanctuary of his inner self and resist those that continually threaten to enter in. The fact that the poet characterizes the living faithful as "étoiles souffrantes" [229] and "ce ciel en travail" [243] signifies that they are suffering salutary labor pains in their struggle to rid themselves of the "boue" and "déguisement" [229] that stand in the way of their becoming star-saints. This battle against the enemies is a slow, long-term process which needs time to come to complete fruition. The fight is also not easy-earlier the poet indicated that the protection against evil assured him by la Force, the second of the Quatre Vertus, comes at the price of a continual engagement in intense and brutal hand to hand combat against a variegated host of enemy forces, both external and internal [158-172]. But despite the difficulty and length of the battle, the victory of the faithful is assured- they are already "étoiles" even if still "souffrantes" [229] and "ciel" even though still "en travail" [229].

The poet's relationship with the enemy-pillagers themselves is complex. Although the spiritual evil of the enemies must be resisted, the pillagers themselves, it seems, must not be condemned [247-8]. Indeed, immediately after his salutation to the century the poet, through an allusion to the forgiving attitude of the Virgin Mary and that of Christ [209-10] appears to forgive the pillagers and offer them the possibility of conversion. ${ }^{9}$ However the poet refuses all direct discourse with the pillagers and leaves it entirely up to them to respond or not to his implicit invitation to conversion. He concentrates his attention rather on exhorting those who have already received his word to continue allowing it to grow within themselves. Even if the enemies (some or all) do not convert and choose to remain spiritually "hors de nous" [247], the faithful are not to be disconcerted, discouraged, or intimidated by these external enemies because they cannot prevent the faithful from themselves becoming star-saints. The only thing that stands in the way of the faithful becoming star-saints is their own internal sinfulness.

The poet concludes his salutation to his faithful brethren and to the star-saints by presenting himself under the guise of a medieval monk returning to his convent from a forced exile only to find it in a state of ruin. Even though the material Church structure no longer exists the monk does not miss it because he preserves intact within his memory and imagination (and the poet's words evoke and describe) its once glorious 


\section{Larissa Christina Bibbee}

and lofty steeple/ bell tower with its four bronze bells [250-2]. These particular architectural details (steeple and bells) of the now defunct Church which are thus recalled by the monk and portrayed by the poet metonymically designate not only the whole of the physical Church structure preserved from ruin in memory and language, but more importantly, exemplify in symbolic terms the fundamental spiritual significance of "Church" as the sacred space where humanity collectively enters into communion with God. ${ }^{10}$ By metonymically remaking the Church edifice in his mind the monk designates symbolically his personal mission of constructing, safeguarding and fortifying the relationships between the community of believers and God which constitute "l'Eglise catholique" [214] in the deepest spiritual sense. He accomplishes this mission by sustaining his relationship with his superior (and by implication with his entire religious community) and copying the gospels (whereby he receives the word of God and transmits it to his brethren) [253-5]. The poet likewise desires and strives to build, protect and promote the spiritual Church by fostering a system of communication between himself, the star-saints and his fellow brethren, and transmitting to the latter the word of life that he receives from God via creation, his gardienne and Christ. ${ }^{11}$

The last section of the Ode [256-288] presents numerous parallels with the first [1-14]. It constitutes in many ways a "corrected version" of the poet's troubled initial relationship with his drama-loving public and underscores the evolution that has taken place within both himself and his public since the beginning of the Ode. In this last section the poet evokes his relationship with the third and final group that constitutes the Catholic Church - the souls in Purgatory. The poet introduces his ministry to the souls of the departed by citing the case of the ancient pagans who once exercised human solidarity vis-à-vis their deceased ancestors by supplying them with real food and drink [264]. The poet actually commends the pagans for their allegiance to their forebears, their sense of obligation to nourish those who had once nourished them [260-1]. Yet he rejects the means by which they chose to express that obligation. He proposes to elevate the pagan ritual of offering a tangible fare of warm wine and chopped meat into a Christian rite of offering prayers and good works.

The pagans' gift of food and drink to their ancestors is in many ways analogous to the poet's gift of theatre to his ex-public - both were given in the hopes of providing solace to fellow comrades in need, but on 


\section{The Poet and his Public in La maison fermée}

a strictly human level. When the poet ceased to create drama for society upon his entrance into the maison fermée, it was not, as his ex-public accused, because he downplayed the ideal of solidarity with his fellow human beings. He could, however, no longer base his relations with them on a "parole" that deliberately excluded God. In her speech la gardienne intimated that, were the public amenable, the poet might offer them the same spiritual word that he was now offering her. But because they appeared to be averse to entering within the maison fermée of God's will, she directed her husband to break off his contact with them and to transfer to her and his child the obligations he once had to them [29-33]. Now that the poet anticipates that the souls in Purgatory will, unlike his expublic, accept his spiritual word, one which will center his relationship with them on God, he demonstrably acknowledges his debt to them for the life — both of body and soul [263] — that they have given him, and it is he himself who takes the initiative to reach out to help them.

But just as the poet's ex-public lamented the loss of his pre-conversion secular drama and thought that he had forsaken his commitment to them, the deceased souls at first seem to regret that he is not one of the ancient pagans he mentions because they would prefer to take the easy way out of their deprivation by seeking a small degree of refuge in the material luxuries of food and drink [279-81]. Like his ex-public, although in a more humble and plaintive tone, they accuse the poet of forgetting them in their need and usurping the resources ("notre terre et nos biens" [279]) that once belonged to them. But in the end they no longer chastise the poet who proposes to share his spiritual treasures with them because they admit that the riches that they most sorely lack and which are most valuable to them are not material ones to feed their decaying bodies but spiritual ones to nourish their still impure souls [282]. Although the spiritual graces that the souls receive do not provide them with immediate relief -indeed their suffering actually increases [284-5] - the reception of the contents of the ciborium will assist them to more quickly eliminate the "résistance détestee" [285] that still excludes them from partaking of the communion cup at the heavenly wedding feast: "La custode seulement et non point la coupe, car nous ne goûterons point de ce fruit de la vigne avant que nous le buvions nouveau dans le Royaume de Dieu" [288].

Because the poet's drama-loving public did not recognize the surpassing value of the transcendent joy towards which he was striving, or their own possible share in it, they also could not discern the sense or 


\section{Larissa Christina Bibbee}

necessity of the self-sacrifice required to attain to it. Suffering was for them simply nonsensical and therefore scandalous and unacceptable. They refused therefore to amend their stance of fierce and sustained rebellion against the adversities of life or to forgo the heady satisfaction of voicing their revolt via theatre. If the souls, on the other hand, consent to abstain from earthly pleasures and resign themselves to their confinement in the fiery prison of Purgatory [283] it is because they realize that the enjoyment of a meager meal here and now would be a poor substitute for the eternal heavenly banquet which, after a temporary period of purification, they will be able to share with God and the saints in the Kingdom of Heaven. In that new and perfect celestial maison fermée all external and internal enemies as well as all suffering will have disappeared, leaving the suffering souls become saints free to enjoy an eternity of unadulterated joy.

Although it is the poet who himself initially reaches out to his deceased ancestors, he quickly involves others in his undertaking. The poet and the faithful contribute in a communal effort to fill the ciborium-the poet exhorts his living brethren to remember the deceased [260-3] and speaks of the contents of the ciborium in the first person plural as "nos moissons....nos bonnes œuvres....nos suffrages...nos mortifications" $[265,269,270]$. The ciborium is then carried up to the souls in Purgatory by "l'ange de Dieu" [266-7], a representative of the celestial sphere (of which the star-saints of the previous stanza were also members). The mobilization of both members of earth and heaven to aid the souls in Purgatory is symbolic of the cooperation and communication uniting all members of the Church in a network of mutual assistance ${ }^{12}$ which it is the poet's vocation to discover, foster and create. Yet the souls in Purgatory and the living faithful, still exiled from heaven, are still to some degree separated from God and the saints as well as from each other. It is only when the living faithful and the souls in Purgatory enter heaven at the end of time as a result - at least in part - of receiving the poet's word, that he will have definitively and successfully accomplished his three-fold mission of uniting each individual to God, the members of the Church to one another and himself to them in an intimate, perfect and indissoluble communion. 


\section{The Poet and his Public in La maison fermée}

\section{Notes}

1 My discussion here focuses only on the poet's relationship with the public that he creates within the textual space of his poem. For a discussion of possible links between the poet's intratextual addressees and his real, extratextual public as well as an analysis of the techniques employed by the poet to give an impression of oral communication with his interlocutors see N. Hellerstein (1994).

2 All numbers in brackets indicate the number of the verse(s) referred to or quoted.

3 For another reading of the public's diatribe against the poet see A. Maurocordato (94-5).

4 The "grand Christ de bronze" [111] is a large and impressive crucifix located near the entrance of the Notre Dame cathedral in Paris.

5 According to A. Maurocordato "[l] a flamme symbolise la foi brûlante et vacillante du jeune homme." (98)

6 M-F. Guyard comments "Le père de la parabole finit par céder à l'importun; ainsi le poète finira par répondre aux appels de ses frères humains. Mais il n'aura pu s'ouvrir à son prochain qu'après avoir "fermé la porte de sa chambre", comme le conseillait Jésus dans le Sermon sur la Montagne." (67)

7 P. Lorigiola explains "Ainsi le poète $a-t-i l$ pour mission de susciter d'autres poètes. Chacun de ses lecteurs, s'il sait communier avec lui, verra l'univers avec le même regard." (43)

8 These events occurred after the passage of a 1905 law decreeing the separation of Church and State in France.

9 In verse 209 the poet imagines that a statue of the Virgin Mary toppled facedown in the snow by the pillagers is "suppliante pour l'iniquité de son peuple" [209]; in the next verse he echoes the crucified Christ's words of forgiveness for his enemies in his description of "tant d'asiles ouverts par la pioche qui ne sait ce qu'elle fait" [210]. The poet seems by way of these images of divine self-sacrifice and forgiveness to be extending to the enemies of the Church the eventual possibility of conversion and reconciliation.

10 The Church's lofty steeple represents humanity's aspiration towards God while the bells symbolize the summoning and gathering together of the community of the faithful to worship God.

11 According to N. Hellerstein, "L'étape des Quatre Vertus débouche ainsi sur un cosmos renouvelé, où le mal présent n'est que l'envers du bien futur. La malédiction des païens, la destruction des églises, la rage de Satan, la dévastation des couvents indiquent que la "maison fermée" de l'univers ne dépend 


\section{Larissa Christina Bibbee}

pas d'un édifice réel, mais existe dans le réseau sacré des rapports entre les choses. C'est ce système sacré des rapports qui forme lui-même la véritable "Église catholique qui est de tout l'univers" (289). Ainsi, le moine dans son couvent dévasté est capable de reconstituer son Église à partir du noyau de la relation sacrée entre lui et son "supérieur au-dessus de lui" (290). (88) (Hellerstein 1990)

12 For an excellent discussion of Claudel's depiction of the communion of saints in this Ode see Kurimura (95-109).

\section{Works cited}

Claudel, Paul. "La Maison fermée." Euvre poétique. Paris: Gallimard, 1957.

Guyard, Marius-François. Recherches claudéliennes: Autour des Cinq Grandes Odes. Paris: Librairie C. Klincksieck, 1963.

Hellerstein, Nina. "Le Poète et ses interlocuteurs dans les Cinq Grandes Odes." Paul Claudel: les odes, poésie, rhétorique, théologie. Ed. Sergio Villani. Ontario: Les Editions Albion Press, 1994. 45-56.

Hellerstein, Nina. Mythe et Structure dans les Cinq Grandes Odes de Paul Claudel. Annales Littéraires de l'Université de Besançon 414. Paris: Les Belles Lettres, 1990.

Kurimura, Michio. La Communion des Saints dans l'œeurre de Paul Claudel. Tokyo: Librairie Editions France Tosho, 1978.

Lorigiola, P. "Les Grandes Odes de Claudel." Les Études Classiques (1959): 273. 292, 382-406; (1960): 30-50.

Maurocordato, Alexandre. L'Ode de Paul Claudel: essai de phénoménologie littéraire. Archives des Lettres Modernes181. Paris: Lettres Modernes, 1978. 